\title{
COVID-19 in Brazil: Opportunity to integrate mental health in the Programa Bolsa Família
}

\author{
Alejandra Álvarez-Iglesias ${ }^{1}$ \\ iD https://orcid.org/0000-0003-4736-3813 \\ Annette Bauer ${ }^{2}$ \\ iD https://orcid.org/0000-0001-5156-1631 \\ Sara Evans-Lacko² \\ https://orcid.org/0000-0003-4691-2630 \\ Alicia Matijasevich ${ }^{3}$ \\ iD https://orcid.org/0000-0003-0060-1589 \\ Cristiane S. Paula 4 \\ (iD) https://orcid.org/0000-0003-0438-9407
}

To cite this paper: Álvarez-Iglesias, A., Bauer, A., Evans-Lacko, S., Matijasevich, A., \& Paula, C. S. (2021). COVID-19 in Brazil: Opportunity to integrate mental health in the Programa Bolsa Família. Psicologia: Teoria e Prática, 23(3), 1-15. doi:10.5935/19806906/ePTPIC14853

\footnotetext{
1 Universidad Autónoma de Madrid, Madrid, Spain.

2 London School of Economics and Political Science, London, UK.

3 Universidade de São Paulo (USP), São Paulo, SP, Brazil.

4 Universidade Presbiteriana Mackenzie (UPM), São Paulo, SP, Brazil.
} 


\begin{abstract}
According to the World Health Organization, Brazil ranks third in COVID-19 cases and second in deaths globally. The most severely impacted by this shock are the approximately 10 million Brazilians that live in extreme poverty. This vulnerability is evident in youth, financially, and in their well-being and mental health. Like other cash transfer programmes globally, the Programa Bolsa Família (PBF) is currently being adapted to support individuals and families during the pandemic. The current environment offers a unique opportunity for PBF to focus on young people and tackle poverty from a broader perspective. The PBF can expand its scope to address the longer-term mental health impacts of economic crises and poverty, besides addressing urgent food security and survival needs. This approach could enhance youth's future life chances and break the vicious cycle between mental illness and poverty that spirals many young people into socioeconomic and mental health disadvantages.
\end{abstract}

Keywords: COVID-19; mental health; social protection; youth; Programa Bolsa Família.

\title{
COVID-19 NO BRASIL: OPORTUNIDADE DE INTEGRAR SAÚDE MENTAL NO PROGRAMA BOLSA FAMÍLIA
}

\section{Resumo}

Segundo a Organização Mundial da Saúde (OMS), o Brasil é o terceiro país do mundo com mais casos de COVID-19 e o segundo em número de mortes. Os mais afetados são os cerca de dez milhões de brasileiros vivendo na linha da pobreza. Essa vulnerabilidade é mais visível entre os jovens, tanto economicamente quanto em relação à saúde mental. Junto a outros programas de transferência de renda, o Programa Bolsa Família (PBF) foi adaptado para melhor contribuir durante a pandemia. Esse contexto oferece uma oportunidade única para que o PBF foque em jovens e aborde a pobreza de forma mais ampla. Além de cobrir as necessidades básicas, o PBF poderia ampliar seu alcance visando a impactos econômicos e de saúde mental de longo prazo. Esse enfoque poderia melhorar as oportunidades de vida de jovens e romper o ciclo vicioso entre problemas de saúde mental e pobreza que os mantêm em situação de vulnerabilidade social.

Palavras-chave: COVID-19; saúde mental; proteção social; juventude; Programa Bolsa Família. 


\title{
SALUD MENTAL DE ESTUDIANTES UNIVERSITARIOS BRASILEÑOS DURANTE LA PANDEMIA COVID-19
}

\begin{abstract}
Resumen
Según la Organización Mundial de la Salud (OMS), Brasil es el tercer país en casos de COVID-19 y el segundo en muertes mundialmente. Los más afectados son los cerca de diez millones de brasileños viviendo en pobreza extrema. Esa vulnerabilidad es particularmente visible en los jóvenes, tanto económicamente como en relación con la salud mental. Junto de otros programas de transferencia de efectivo a nivel mundial, el Programa Bolsa Família (PBF) se está adaptando para ayudar durante la pandemia. Ese contexto ofrece una oportunidad única para que el PBF se centre en los jóvenes y aborde la pobreza más ampliamente. Además de cubrir necesidades básicas, el PBF puede ampliar su alcance atajando los impactos a largo plazo de pandemias y crisis económicas en salud mental. Este enfoque podría mejorar las oportunidades de vida de los jóvenes y romper el círculo vicioso de enfermedad mental y pobreza que les conduce a una situación de desventaja.

Palabras clave: COVID-19; salud mental; protección social; juventud; Programa Bolsa Família.
\end{abstract}

\section{The impacts and responses to socioeconomic and mental} health challenges of young people during the COVID-19 pandemic in the Brazil: An opportunity for integration of mental health in the Programa Bolsa Família

\subsection{Global context: COVID-19, youth, and conditional cash transfer programmes}

According to recent World Bank estimates, it is expected that, as a result of the COVID-19 pandemic, up to an additional 150 million people globally will fall into extreme poverty by 2021 (The World Bank, 2020a). It has also been estimated that the rise in unemployment from the pandemic caused young people to lose $\$ 1.29$ trillion of earnings globally in 2020 (Kutwa, 2021).

In addition to the economic damage, the pandemic has also negatively affected many individuals' mental health (Rajkumar, 2020). Literature has globally highlighted the deterioration of youth mental health or at least a greater tendency to have psychological problems resulting from the pandemic, leading to long-term consequences (Holmes et al., 2020; Jiao et al., 2020; Liang et al., 2020). Such 
psychological burden may result in low productivity (Evans-Lacko \& Knapp, 2016) and limited decision-making ability (Bishop \& Gagne, 2018) that can harm young people's future life chances in this challenging environment.

Conditional cash transfer programs (CCTs) - which are widely used as a social protection measure and consist of making direct payments to people identified as living in poverty subject to complying with a defined set of behaviours - can have a range of positive effects not only on reducing poverty but on wider health and well-being (Fiszbein \& Schady, 2009). These include better education through increased school attendance (a typical condition for CCTs) and improved economic circumstances and mental health for children and young people (Zimmerman et al., 2021).

As cash transfer programmes adapt globally to respond to the challenges of the COVID-19 pandemic, at CHANCES-6 - a research project that seeks to generate knowledge about the role of these programmes in improving youth mental health - we believe there is an opportunity to further strengthen their strategies by prioritising young peoples' mental health. In a recently published commentary (Bauer et al., 2021), we made recommendations about expanding the scope of cash transfer programmes to address the longer-term consequences of the macroeconomic crisis on youth mental health and their future life chances. In this article, we reflect on how our recommendations translate to the Brazilian context, particularly regarding the country's main CCT, the Programa Bolsa Família (PBF).

\subsection{Impact of the COVID-19 pandemic on the economy of Brazil and its young people}

As of June 18th, 2021, Brazil ranked third globally in cumulative COVID-19 cases with 17.6 million and second in most deaths with over 490 thousand (World Health Organization, 2021). The country's more contagious variant (P1), which seems to affect the young more than older people (Castro, 2021), is reportedly bringing the health system close to a collapse. With hospitals reaching full capacity across states (Taylor, 2021), the crisis is still far from being controlled and its full economic impact is yet to be seen. 
In Brazil, a country where close to 10 million individuals live in extreme poverty (defined as living on less than BRL\$ 4.9 or US\$ 1.9 per day), and $35 \%$ of children under 14 are poor (living on less than BRL\$14.3 or US\$ 5.5 per day) (The World Bank, 2021), the economic impact of the COVID-19 pandemic has been significant. With at least 26 million workers estimated to be lacking access to any compensation, this crisis is expected to have moved $83.5 \%$ of the labour market in Brazil into a state of vulnerability (Barbosa \& Prates, 2020).

This vulnerability is particularly visible in young workers. In 2019, $23.5 \%$ of young people (aged 15 to 24 ) in Brazil were not in employment, education, or training (NEET) (International Labour Organisation, 2021). Between the first and second quarters of 2020, their post-support labour income (including compensation received even if not working, like furloughed employees) declined by $30.1 \%$ due to the COVID-19 crisis (International Labour Organisation, 2021). This demonstrates a greater impact than the national unemployment rate, which increased from $12.2 \%$ in the first quarter of 2020 (The World Bank, 2020b) to $14.4 \%$ by February 2021 (Moody's Analytics, 2021).

\subsection{Impact of the COVID-19 pandemic on mental health among Brazil's youth}

The significant disruptions experienced by Brazilians in their daily lives due to the pandemic-driven combination of a negative economic shock and psychological distress result in a visibly negative impact on their mental health.

Several studies conducted throughout 2020 reveal a high prevalence of psychological problems like anxiety or depression among Brazil's population (Goularte et al., 2021; Passos, Prazeres, Teixeira, \& Martins, 2020). A survey of 1,996 individuals identified that young people, individuals with low income, and those with low education levels were among the most susceptible groups presenting severe symptoms of anxiety, depression, and stress (Goularte et al., 2021). Studies in other countries highlight some of the factors related to poverty that may contribute to mental health deterioration among young people during the pandemic. These include lack of access to school mental health services during lockdowns (Golberstein, Wen, \& Miller, 2020) and negative changes in parents' work situation (Luijten et al., 2021). 


\subsection{Brazil's adjustments to the Programa Bolsa Família in response to the COVID-19 crisis}

To tackle the economic shock caused by COVID-19, the Brazilian government announced a stimulus package in March 2020. It comprised multiple measures, including the provision of credit and loans for micro, small, and medium-sized enterprises, relaxation of labour laws to maintain jobs, and extension of tax payments among others. As part of these initiatives, certain adjustments were introduced to Brazil's flagship CCT, the Programa Bolsa Família. PBF was first introduced in 2003 to break the poverty cycle by providing a minimum income level to extremely poor families conditioned to their investment in human capital (notably education, vaccinations, and medical consultations). In March 2020, the reach of PBF was expanded, adding over 1 million new families who were eligible but on a waiting list due to budgetary constraints, resulting in approximately 14 million families receiving coverage between March 2020 and March 2021 (International Monetary Fund, 2021). In addition, and in line with other countries' measures during this health crisis, conditionalities of the program were suspended, with the view that as soon as services resume normal operations (e.g., schools reopen for traditional classes), they will be reinstated.

However, whilst the expansion of PBF is positive, this could also be perceived as a mere 'catch-up' after several years of reduction and exclusion in the number of beneficiaries and drop in the average amounts transferred.

Following the programme's growth from 3 million beneficiaries in 2004 to 14 million in 2017, in July of the same year, more than one million families were excluded, and from then until February 2020 the number of families enrolled remained stable at 13 million. Moreover, since the expansion of the programme in March 2020, new admissions have been indefinitely suspended, and the number of families on the waiting list by December was more than 2.1 million (CECAD 2.0, 2021); and more recently the federal government has revealed its plan to centralise the registration process for new beneficiaries, removing autonomy from the municipalities that are currently in charge, in order to reduce costs of social protection policies (Cavallini, 2021).

\subsection{Mental health policy response}

In terms of mental health policies, Brazil's public Unified Health System (Sistema Único de Saúde - SUS) created an online health and mental health support 
network. Also, in 2020, the mental health sector received an additional BRL\$ 65 million (US\$ 15 million) for different types of services. However, of this amount, only half was targeted to the Centres for Psychosocial Care (CAPS - community based specialty mental health centres), considered the main source of mental healthcare inside the SUS.

However, like in the case of PBF, these initiatives may not be sufficient, as there is limited visibility on the capacity by the public healthcare system to face this crisis in a country where $56 \%$ of total health expenditure is private (Andrietta et al., 2020) and the public system has been notoriously underfunded since the austerity measures, introduced in 2018 (Hone et al., 2019).

In addition, the most recent and controversial Federal Law that guides the national mental health system (Plataforma Brasileira de Política de Drogas, 2019) has had repercussions in different Psychology, Psychiatry, and Public Health associations. This law prioritises additional funds to psychiatric beds and therapeutic communities for drug/alcohol addiction in detriment of investments into the CAPS. Moreover, this regulation implements a new type of outpatient unit for less severe cases, which, in practice, may result in resource allocation conflicts with the CAPS.

\subsection{Integrating mental health into the Programa Bolsa Família}

The COVID-19 pandemic has highlighted the vulnerability of young people living in poverty facing the negative economic and psychological effects of this crisis. Equally, it has emphasized the power of CCTs to mitigate negative impacts and shocks to other vulnerable groups.

We have seen some individual responses to the current crisis at both Brazil's economic and mental health levels. We believe, however, that there is an opportunity for CCTs to deliver a holistic response that focuses on young people, considering the vulnerability of this large group and the broad reach of some programmes like PBF.

This crisis has stressed the importance of considering economic and mental health challenges together, as they might be interconnected. Literature shows that poverty and mental health problems interact in a negative cycle across the life course (Haushofer \& Fehr, 2014; Lund et al., 2011). Consequently, young individuals who are losing their jobs during the pandemic can become more vulnerable to develop mental health problems, which would affect their future ability to (re-)gain employment and escape poverty. Equally, those with the existing conditions may worsen, facing 
similar negative long-term consequences. This situation can be exacerbated or perpetuated in the future, driven by the economic shock from COVID-19 and the indefinite duration of the pandemic itself, already approaching its third wave.

The pandemic has also offered an opportunity for policymakers to identify the limitations and opportunities of existing CCTs and to tackle economic and mental health issues jointly and more effectively. CCTs like the Programa Bolsa Família, which have a long reach, are ideally positioned to spearhead this effort by implementing certain initiatives to promote mental health.

CHANCES- 6 explores how collaboration between researchers, policymakers, and implementers can enhance the promotion of mental health by programmes. In our aim to assist in this process, we highlight certain considerations when integrating mental health into existing cash transfer programmes. In the context of Brazil's PBF, we believe the following are important to consider:

- Targeting young people more susceptible to developing mental health conditions by identifying clusters of populations with risk factors. PBF already has a strong infrastructure and administrative systems in place to identify and support young people with or at risk of developing mental health problems. This is demonstrated by PBF's extensive reach, covering over 14 million families (or approximately $25 \%$ of the population) with variable benefits for those with children and studying teenagers. Further improvements to maximise the identification and contact of these individuals could include cooperation with CAPS (Centres for Psychosocial Care, which are considered one of the best sources of identification of individuals with mental health issues in the country), or leveraging Brazil's CadUnico, a single registry of all the households in the country that apply for PBF and other public services. There is an opportunity to leverage the proliferation of mobile phones among young people to accelerate engagement and enable access to assistance to those who are unable to physically reach help. Promising initiatives in this direction are the various online services that have been made available during the crisis.

- Exploring the provision of psychoeducational resources to support mental health and avoid the psychological threats of misinformation about COVID-19. In Brazil, dissemination of fake news and systematic denial of the pandemic has had clear repercussions on the infections and attitude 
towards vaccination (Barcelos et al., 2021; Cabral et al., 2021; Recuero et al., 2020). The confusion created by distorted facts and conflicting messages contributed to intolerance of uncertainty that may be considered as a transdiagnostic factor related to mental health problems like depression or anxiety (Ferreira et al., 2020). This stresses the importance of taking actions to preserve mental health against misinformation flows. The Pan American Health Organization (PAHO) has generated a wide range of educational content available online to help people make informed decisions and prevent the consequences of rumours and misinformation about the virus (including fake news). Among this content, there are specific media cards and videos oriented to parents and children in a clear, simple language that can be easily understood by families across all segments of the population. In Brazil, the Ministry of Health collaborated with PAHO and the World Health Organization (WHO) in campaigns that aim to mitigate the stigma and encourage empathy to those affected by the disease and the professionals helping on the front line (Organização Pan-Americana Da Saúde, 2020). Partnerships between CCTs and trustable institutions can be valuable to fulfil this goal, especially considering the physical footprint of PBF. The programme's centres can serve as a springboard to disseminate informative resources beyond the digital realm.

- Facilitating access to mental health support for young people and, if the available infrastructure and resources permit it, fully integrating mental health interventions as part of CCTs. Currently, social and mental health programmes for young people are not integrated into the CCTs. One example would be the Brazilian parent coaching programme Criança Feliz, launched in 2016 to help parents have a more loving relationship with their children. It provides access to soft skills training and mental health interventions, and it leverages PBF's infrastructure, but there is no full integration between the two of them. Whilst Criança Feliz targets early years of parenthood (up to two years), a full integration of PBF with similar types of interventions focused on a wider age range may ultimately boost resilience in young PBF beneficiaries by facilitating emotional, cognitive and behavioral skills.

- Assessing the mental health impact of the programmes. Incorporating this new dimension in the evaluation of CCTs like PBF would not only provide 
invaluable insight into the scale and relevance of mental health issues during crises, but also data on how these programmes help address such problems. This would ultimately help in understanding the relationship between poverty, mental health, and life chances. Currently, there are not specific publications about the impact of PBF on youth mental health, although a recent systematic review has revealed several positive aspects of PBF on this topic (Neves et al., 2020).

There are several examples of synergistic integrations between CCTs and other initiatives across Latin American countries, and we believe similar approaches would be beneficial for PBF in Brazil. In Mexico and Colombia, their CCTs (ProgresaOportunidades-Prospera and Familias en Acción, respectively) have included parents' attendance to nutrition and childcare meetings as a condition to receiving the cash transfer (Barrientos et al., 2013). These creative ways to incorporate new features into CCTs to provide families with skillsets that can improve the overall lives of their children are very encouraging, and we believe mental health is a critical area to cover.

Our understanding of the relationship between poverty and mental health, particularly in vulnerable populations like youth, during current economic uncertainty times, makes the integration of mental health and social protection programmes more salient for young people's life chances. At CHANCES-6, we believe mental health professionals have an important role in advocating for changes to conditional cash transfer programmes so that they support youth mental health.

\section{References}

Andrietta, L. S., Levi, M. L., Scheffer, M. C., Alves, M. T. S. S. de B., Oliveira, B. L. C. A., \& Russo, G. (2020). The differential impact of economic recessions on health systems in middle-income settings: A comparative case study of unequal states in Brazil. BMJ Global Health, 5(2), e0o2122, 1-11. doi:10.1136/bmjgh-2019-002122

Barbosa, R., \& Prates, I. (2020). Efeitos do desemprego, do Auxílio Emergencial e do Programa Emergencial de Preservação do Emprego e da Renda (MP 936) sobre a renda, a pobreza e a desigualdade durante e depois da pandemia. SSRN Electronic Journal. doi:10.2139/ssrn.3630693 
Barcelos, T. do N. de, Muniz, L. N., Dantas, D. M., Cotrim Junior, D. F., Cavalcante, J. R., \& Faerstein, E. (2021). Análise de fake news veiculadas durante a pandemia de COVID-19 no Brasil. Revista Panamericana de Salud Pública, 45, e65, 1-8. doi:10.26633/ RPSP.2021.65

Barrientos, A., Byrne, J., Villa, J. M., \& Peña, P. (2013). Social Transfers and Child Protection. Innocenti Working Papers. Retrieved from https://www.unicef-irc.org/publications/691-social-transfers-and-child-protection.html

Bauer, A., Garman, E., McDaid, D., Avendano, M., Hessel, P., Díaz, Y., Araya, R., ... Evans-Lacko, S. (2021). Integrating youth mental health into cash transfer programmes in response to the COVID-19 crisis in low-income and middle-income countries. The Lancet Psychiatry, 8(4), 340-346. doi:10.1016/S2215-0366(20)30382-5

Bishop, S. J., \& Gagne, C. (2018). Anxiety, Depression, and Decision Making: A Computational Perspective. Annual Review of Neuroscience, 41(1), 371-388. doi:10.1146/ annurev-neuro-080317-062007

Cabral, S., Pongeluppe, L., \& Ito, N. (2021). The Disastrous Effects of Leaders in Denial: Evidence from the COVID-19 Crisis in Brazil. SSRN Electronic Journal. doi:10.2139/ ssrn. 3836147

Castro, R. (2021, April 1st). Fiocruz Bulletin COVID-19 alerts that pandemic is getting younger in Brazil. Retrieved from https://portal.fiocruz.br/en/news/fiocruz-bulletincovid-19-alerts-pandemic-getting-younger-brazil

Cavallini, M. (2021, March 14). Crise faz aumentar busca pelo Bolsa Família, e mais de 2,1 milhões de famílias estão na fila do benefício. G1. Retrieved from https://g1. globo.com/economia/noticia/2021/03/14/crise-faz-aumentar-busca-pelo-bolsafamilia-e-mais-de-21-milhoes-de-familias-estao-na-fila-do-beneficio.ghtml

CECAD 2.o. (2021). Programa Bolsa Família. Famílias Beneficiárias. Retrieved from https:// cecad.cidadania.gov.br/agregado/resumovariavelCecad.php?uf_ibge=6\&nome_ estado $=$ Brasil\&id $=79$

Evans-Lacko, S., \& Knapp, M. (2016). Global patterns of workplace productivity for people with depression: Absenteeism and presenteeism costs across eight diverse countries. Social Psychiatry and Psychiatric Epidemiology, 51(11), 1525-1537. doi:10.1007/s00127-016-1278-4

Ferreira, D. C. S., Oliveira, W. L., Delabrida, Z. N. C., Faro, A., \& Cerqueira-Santos, E. (2020). Intolerance of uncertainty and mental health in Brazil during the COVID-19 pandemic. Suma Psicológica, 27(1), 62-69. doi:10.14349/sumapsi.2020.v27.n1.8 
Fiszbein, A., \& Schady, N. R. (2009). Conditional cash transfers: Reducing present and future poverty. World Bank Policy Research Report. Washington, DC: World Bank.

Golberstein, E., Wen, H., \& Miller, B. F. (2020). Coronavirus Disease 2019 (COVID-19) and Mental Health for Children and Adolescents. JAMA Pediatrics, 174(9). doi:10.1001/ jamapediatrics.2020.1456

Goularte, J. F., Serafim, S. D., Colombo, R., Hogg, B., Caldieraro, M. A., \& Rosa, A. R. (2021). COVID-19 and mental health in Brazil: Psychiatric symptoms in the general population. Journal of Psychiatric Research, 132, 32-37. doi:10.1016/j.jpsychires. 2020.09.021

Governo do Brasil. (2020, December 10). Investidos R\$ 99 milhões para ampliar o atendimento dos Centros de Atenção Psicossocial. Brasília, DFÇ: Governo Federal, Casa Civil. Retrieved from https://www.gov.br/casacivil/pt-br/assuntos/noticias/2020/ dezembro/investidos-r-99-milhoes-para-ampliar-o-atendimento-dos-centros-deatencao-psicossocial

Haushofer, J., \& Fehr, E. (2014). On the psychology of poverty. Science, 344(6186). doi:10.1126/science.1232491

Holmes, E. A., O'Connor, R. C., Perry, V. H., Tracey, I., Wessely, S., Arseneault, L., ... Bullmore, E. (2020). Multidisciplinary research priorities for the COVID-19 pandemic: A call for action for mental health science. The Lancet Psychiatry, 7(6). doi:10.1016/ S2215-0366(20)30168-1

Hone, T., Mirelman, A. J., Rasella, D., Paes-Sousa, R., Barreto, M. L., Rocha, R., \& Millett, C. (2019). Effect of economic recession and impact of health and social protection expenditures on adult mortality: A longitudinal analysis of 5565 Brazilian municipalities. The Lancet Global Health, 7(11). doi:10.1016/S2214-109X(19)30409-7

International Labour Organisation. (2021). ILO Monitor: COVID-19 and the world of work. Seventh edition. Updated estimates and analysis. Retrieved from https://www.ilo. org/wcmsp5/groups/public/@dgreports/@dcomm/documents/briefingnote/ wcms_767028.pdf

International Monetary Fund. (2021). Policy Responses to COVID-19. Washington, D.C. Retrieved from https://www.imf.org/en/Topics/imf-and-covid19/Policy-Responsesto-COVID-19

Jiao, W. Y., Wang, L. N., Liu, J., Fang, S. F., Jiao, F. Y., Pettoello-Mantovani, M., \& Somekh, E. (2020). Behavioral and Emotional Disorders in Children during the COVID-19 Epidemic. The Journal of Pediatrics, 221. doi:10.1016/j.jpeds.2020.03.013 
Kutwa, K. (2021). Corona Generation. Growing Up in a Pandemic. Retrieved from https://pie. net.pl/wp-content/uploads/2021/03/PIE-Corona-Generation.pdf

Liang, L., Ren, H., Cao, R., Hu, Y., Qin, Z., Li, C., \& Mei, S. (2020). The Effect of COVID-19 on Youth Mental Health. Psychiatric Quarterly, 91(3), 841-852. doi:10.1007/ s11126-020-09744-3

Luijten, M. A. J., van Muilekom, M. M., Teela, L., Polderman, T. J. C., Terwee, C. B., Zijlmans, J., ... Haverman, L. (2021). The impact of lockdown during the COVID-19 pandemic on mental and social health of children and adolescents. Quality of Life Research. doi:10.1007/s11136-021-02861-x

Lund, C., de Silva, M., Plagerson, S., Cooper, S., Chisholm, D., Das, J., ... Patel, V. (2011). Poverty and mental disorders: breaking the cycle in low-income and middleincome countries. The Lancet, 378(9801), 1502-1514. doi:10.1016/S01406736(11)60754-X

Moody's Analytics. (2021). Brazil: Unemployment Rate. Retrieved from https://www. economy.com/brazil/unemployment-rate

Neves, J. A., Vasconcelos, F. de A. G. de, Machado, M. L., Recine, E., Garcia, G. S., \& Medeiros, M. A. T. de. (2020). The Brazilian cash transfer program (Bolsa Família): A tool for reducing inequalities and achieving social rights in Brazil. Global Public Health. doi:10.1080/17441692.2020.1850828

Organização Pan-Americana da Saúde. (2020). COVID-19: Uma mensagem para você. Recuperado de Https://Www.Youtube.Com/Watch?V=53Cpwbid5sU

Passos, L., Prazeres, F., Teixeira, A., \& Martins, C. (2020). Impact on mental health due to Covid-19 pandemic: Cross-sectional study in Portugal and Brazil. International Journal of Environmental Research and Public Health, 17(18), 6794. doi:10.3390/ ijerph17186794

Plataforma Brasileira de Política de Drogas. (2019, November). Esclarecimentos sobre as mudanças na Política Nacional de Saúde Mental e nas Diretrizes da Política Nacional sobre Drogas. Retrieved from http://pbpd.org.br/wp-content/uploads/ 2019/02/0656ad6e.pdf

Rajkumar, R. P. (2020). COVID-19 and mental health: A review of the existing literature. Asian Journal of Psychiatry, 52, 102066. doi:10.1016/j.ajp.2020.102066

Recuero, R., Soares, F. B., Vinhas, O., Volcan, T., Zago, G., Stumpf, E. M., ... Sodré, G. (2021). Desinformação, mídia social e Covid-19 no Brasil: Relatório, resultados e estraté- 
gias de combate. Pelotas, RS : MIDIARS - Grupo de Pesquisa em Mídia Discurso e Análise de Redes Sociais. Retrieved from https://wp.ufpel.edu.br/midiars/files/ 2021/05/Desinformac\%CC\%A7a\%CC\%830-covid-midiars-2021-1.pdf

Taylor, L. (2021). Covid-19: Brazil's hospitals close to collapse as cases reach record high. BMJ, 372(800). doi:10.1136/bmj.n800

The World Bank. (2020a, October 7th). COVID-19 to add as many as 150 million extreme poor by 2021. Press Release NO: 2021/024/DEC-GPV. Retrieved from https://www.worldbank.org/en/news/press-release/2020/10/07/covid-19-to-add-as-manyas-150-million-extreme-poor-by-2021

The World Bank. (2020b). COVID-19 in Brazil: Impacts and policy responses. Washington, DC: The World Bank. Retrieved from https://openknowledge.worldbank.org/bitstream/handle/10986/34223/COVID-19-in-Brazil.pdf?sequence=4\&isAllowed=y

The World Bank. (2021). Poverty \& Equity Brief Latin America \& the Caribbean: Brazil. Washington, DC: The World Bank. Retrieved from https://databank.worldbank.org/data/ download/poverty/987B9C90-CB9F-4D93-AE8C-750588BFooQA/AM2020/ Global_POVEQ_BRA.pdf

World Health Organization. (2021, June 29th). WHO COVID-19 Global Table Data. Retrieved from https://covid19.who.int/table

Zimmerman, A., Garman, E., Avendano-Pabon, M., Araya, R., Evans-Lacko, S., McDaid, D., ... Lund, C. (2021). The impact of cash transfers on mental health in children and young people in low-income and middle-income countries: A systematic review and meta-analysis. BMJ Global Health, 6(4). https://doi.org/10.1136/bmjgh2020-004661

\section{Authors' note}

Alejandra Álvarez-Iglesias, Departamento de Psicología Biológica y de la Salud, Facultad de Psicología, Universidad Autónoma de Madrid; Annette Bauer, Care Policy and Evaluation Centre, Department of Health Policy, London School of Economics and Political Science; Sara Evans-Lacko, Care Policy and Evaluation Centre, Department of Health Policy, London School of Economics and Political Science; Alicia Matijasevich, Departamento de Medicina Preventiva, Faculdade de Medicina, Universidade de São Paulo (USP);

Cristiane S. Paula, Programa de Pós-Graduação em Distúrbios do Desenvolvimento (PPGDD), Universidade Presbiteriana Mackenzie (UPM). 
This article was supported by a grant from the UK Economic and Social Research Council (ESRC, ES/S001050/1) for the project: "Poverty reduction, mental health and the chances of young people: understanding mechanisms through analyses from 6 low- and middle-income countries (CHANCES-6)" (UK Research and Innovation Global Challenges Research Fund).

Support from the Brazilian National Council for Scientific and Technological Development (Conselho Nacional de Desenvolvimento Científico e Tecnológico - CNPq).

Financial support from the CNPq and the CAPES/Proex (Coordenação de Aperfeiçoamento de Pessoal de Nível Superior) grant no. 0653/2018; CAPES/PrInt grant no. 88887.310343/2018-00.

Acknowledgment: CAPES/PrInt grant no. 88887.310343/2018-00.

Correspondence concerning this article should be addressed to Cristiane Silvestre de Paula, Programa de Pós-Graduação em Distúrbios do Desenvolvimento (prédio 28, $1^{\text {a }}$ andar), Universidade Presbiteriana Mackenzie, Rua Consolação, 930, Consolação, São Paulo, SP, Brazil. CEP 01302-907.

E-mail: cristiane.paula@mackenzie.br

EDITORIAL BOARD

Editor-in-chief

Cristiane Silvestre de Paula

\section{Associated editors}

Alessandra Gotuzo Seabra

Ana Alexandra Caldas Osório

Luiz Renato Rodrigues Carreiro

Maria Cristina Triguero Veloz Teixeira

\section{Section editors}

Psychological Evaluation

Alexandre Serpa

Luiz Renato Rodrigues Carreiro

Vera Lúcia Esteves Mateus

\section{Psychology and Education}

Alessandra Gotuzo Seabra

Carlo Schmidt

Regina Basso Zanon

\section{Social Psychology \\ Enzo Banti Bissoli}

\section{Clinical Psychology}

Carolina Andrea Ziebold Jorquera

Julia Garcia Durand

Natalia Becker

\section{Human Development}

Maria Cristina Triguero Veloz Teixeira Rosane Lowenthal

\section{Technical support}

Maria Fernanda Liuti Bento da Silva Camila Fragoso Ribeiro
EDITORIAL PRODUCTION

Publishing coordination

Ana Claudia de Mauro

Editorial intern

Júlia Lins Reis

Élcio Carvalho

\section{Language editor}

Daniel Leão

\section{Layout designer}

Acqua Estúdio Gráfico 